\title{
Murine experimental models for studying the pathogenesis of coxsackieviruses
}

\author{
S. BOPEGAMAGE ${ }^{1}$, B. BENKÖOVÁ 1 M. POSPIŠILOVÁ ${ }^{1}$, C. KLEMENT T2,3
}

\begin{abstract}
${ }^{1}$ Enterovirus Laboratory, Institute of Microbiology, Faculty of Medicine, Slovak Medical University, Limbová 12, 83303 Bratislava, Slovak Republic; ${ }^{2}$ Regional Public Health Authority in Banská Bystrica, Banská Bystrica, Slovak Republic; ${ }^{3}$ Faculty of Health, Slovak Medical University, Banská Bystrica, Slovak Republic
\end{abstract}

\begin{abstract}
Summary.-Understanding the pathogenesis of communicable diseases often involves animal models. Mouse models are studied by researchers to achieve a better understanding of the relationship between the biological, physiochemical, and antigenic properties of the infectious agent, as well as the histopathological, immunological, and functional changes in the living system and the target organs, in short, the pathophysiological processes that the communicable agents bring about. The long-term objectives of the in vivo studies are important from a medical point of view, as they represent faithful (reliable and similar) human responses, which enhance the development of diagnostics, treatment, and measures for preventing the spread of the disease. Our work is devoted to the murine models used for understanding the pathogenesis of coxsackieviruses. We describe different mouse models used for studying the diseases caused by coxsackieviruses and the immune responses in different mouse models. We then shortly elucidate experiences from our laboratory related to the oral route of infection, and compare the similarities and differences we found in this model.
\end{abstract}

Keywords: pathogenesis; coxsackievirus; murine models

\section{Introduction}

Enteroviruses (EVs) belong to the family Picornaviridae. At first these viruses were subclassified on the basis of their ability to replicate in primates (poliovirus) or mice (coxsackieviruses) complemented with their growth in different cells of human and primate origin. Use of cell cultures resulted in the discovery of Enteric Cytopathogenic Human Orphan (ECHO) viruses, which do not infect mice. Further classification was based on the serological relatedness. Looking back, the human enteroviruses were originally divided into: polioviruses (PV), serotypes 1,2,3; coxsackievirus groups A (CVA) with serotypes 1 to 22 and 24 and $B(C V B)$ with serotypes 1 to 6 ; and echoviruses serotypes 1 to 7, 9, 11 to 27 and 29 to 33 (Melnick, 1996). Introduction of molecular techniques and genetic analysis have

E-mail: shubhada.bopegamage@szu.sk; phone: +421-2-593-70-777. Abbreviations: $\mathrm{CV}$ = coxsackievirus; $\mathrm{CAR}=$ coxsackievirus-adenovirus receptor; ECHO = Enteric Cytopathogenic Human Orphan; IFN = interferon; p.i. = post-infection; VP1 = viral protein 1 resulted in a constant redefining of the classification such as ECHO viruses 22 and 23 which are presently classified as parechoviruses 1 and 2, but the rhinoviruses are now included in the genus Enterovirus (www.picornaviridae. com). Currently, the genus Enterovirus is classified into fifteen species of which seven (Enterovirus -A, -B, -C and $-D$, and Rhinovirus $-A,-B,-C$ ) are human pathogens. These viruses are transmitted by the faecal-oral and respiratory routes (https://talk.ictvonline.org/taxonomy/; http:// www.picornaviridae.com/enterovirus/enterovirus. htm). The extent of viral injury, viral persistence, strain of infecting virus, host genetics, molecular mimicry, involvement of the immune response, and autoimmunity all have been implicated in the pathogenesis of these diseases (Bopegamage, 2016; Muehlenbachs et al., 2015; Pallansch and Roos, 2007).

\section{Coxsackieviruses}

Dalldorf and Sickles (1948) isolated viruses from the faeces of two boys from the village Coxsackie, New York, 
who were suspected of suffering from paralytic poliomyelitis. These viruses were highly pathogenic to newborn mice but to not adult mice. During the initial mouse model studies, suckling white mice 3-7 days old inoculated intracranially with $20 \%$ suspension of the stool sample, resulted in severe pathogenic changes with generalized skeletal muscle destruction (Dalldorf and Sickles, 1948; Gifford and Dalldorf,1951). Henceforth, the coxsackieviruses were divided into two sub-groups based on their pathogenicity in suckling mice. In the experimental mouse (suckling) model, four to five days after infection with CVA striated muscles were attacked, extensive lesions were produced, and generalized myositis of skeletal muscle and flaccid paralysis were observed leading to death within two days (Dalldorf and Melnick, 1965). In addition to the newborn mice, some CVA strains can infect adult mice, hamsters, ferrets, bats, and monkeys, mostly sub-clinically but in some circumstances with overt-infection. Besides being able to infect the immature skeletal muscles of newborn mice, coxsackieviruses can infect surgically denervated muscles of adult mice, whereas mature, innervated muscles are relatively resistant (Melnick, 1996).

The CVB viruses replicate well in both primate cell cultures and in suckling mice. In mice, these viruses cause pathological changes in several tissues. They produce focal myositis, degeneration of neuronal tissue, and encephalomalacia leading to spastic paralysis and pancreatic necrosis (Melnick, 1996).

\section{Clinical manifestations}

Infections caused by the six serotypes of CVBs often lead to only mild diseases. These infections are asymptomatic, they appear as undifferentiated febrile illness, as infections with mild upper respiratory symptoms or as several serious diseases even fatal in some cases - especially in neonates and immune-compromised patients (Muehlenbachs et al., 2015; Pallansch and Roos, 2007). Diseases associated with CVB infections may develop from an acute phase into chronicity, which might in the long term seriously affect the health of an individual. Therefore, a patient with even mild symptoms of CVs infection might be at considerable risk.

CVBs have been particularly implicated in chronic inflammatory diseases such as chronic myocarditis, pancreatitis, type I insulin-dependent diabetes mellitus (T1D), some neurological muscle diseases, and chronic fatigue syndrome (Chapman et al., 1997; Frisk and Diderholm, 1997; Gauntt and Huber, 2003; Hyoty et al., 1998; Hyoty and Taylor, 2002; Jun and Yoon, 2001; Kim et al., 2001; Muir et al., 1989; Roivainen et al., 1995; Pallansch and Roos, 2007; Precechtelova et al., 2014; Swanink et al., 1994; Vreugdenhil et al., 1998).

\section{Coxsackievirus receptors}

The range of diseases associated with CVB reflects the broad tissue tropism of these viruses. They may target organs such as striated muscles, myocardium, brain, spinal cord, lung, skin, and pancreatic islets. Within a given serotype one may find strains and variants that differ in virulence. The variation in the tissue tropism of these viruses and other enteroviruses is partially controlled by the interaction of virion surface residues with the membrane proteins of target cells. The receptor-binding characteristics of the virus may also account for differences in the virulence of the virus and pathological changes caused by them. Therefore, the nature of the infection (acute, chronic, or reinfection) is modulated by the local expression of appropriate cellular receptors and co-receptors, such as coxsackievirus-adenovirus receptor (CAR), the internalisation receptors integrins VLA-2, $\alpha_{v} \beta_{3}$, $\alpha_{v} \beta_{5}$ (very late antigen), intracellular adhesion molecule 1 (ICAM-1), nucleolin, heparin sulphate proteoglycans, and decay accelerating factor (DAF) (Bergelson et al., 1997; Noutsias et al., 2001; Shafren, 1998; de Verdugo et al., 1995; Zautner et al., 2003). These receptors bind the viruses, but may often activate a series of reactions influencing the organ-specific outcome of the disease (Ito et al., 2000; Selinka et al., 2004). The human scavenger receptor class B (SCARB2) plays an important role in some CVA (in particular CV-A7, CV-A10, CV-A14, CV-A16) and in EV-A71 (enterovirus A71) infections (Yamayoshi et al., 2012).

\section{Experimental mouse models}

Humans are the natural hosts for CVB infections. However, these viruses induce clinical manifestations in mice similar to those they cause in humans. Bergelson et al. (1998) have identified mouse coxsackie-adenovirus receptors (mCAR) which are similar to the human receptors (hCAR). Therefore, the murine model is ideal for studying and understanding the pathogenesis of coxsackieviruses and their role in the development of some of the diseases associated with these viruses. Genetic background and the route of infection (intraperitoneal, intracranial, oral, intramuscular, intranasal, and subcutaneous) play important roles in the experimental infection of mice. Intraperitoneal route has been the most common route used for experimentalCVBinfection of experimental mice. While studying pathogenesis, outcome of the experimental infection using different routes of infection are important. The findings can be used for therapy and prevention of diseases.

Inoculation of newborn mice of differing genetic backgrounds with laboratory strains of CVB 1-6 serotypes showed that $\mathrm{C} 3 \mathrm{H}$ mice are resistant to all six serotypes, 
whereas Balb/c mice are the most susceptible. Swiss mice and a randomly bred Swiss strain $\mathrm{COH}$ mice have intermediate susceptibility (Minnich and Ray, 1980).

\section{Mouse strains and CVB3}

Coxsackievirus B3 (CVB3) infections are the most frequent causes of human myocarditis, often resulting in chronic stages characterized by fibrosis and loss of function or "dilated cardiomyopathy" (DCM). Different views exist about the persistence of virus in the myocardium, which may lead to chronic activation of fibroblasts and, subsequently, to fibrosis of the myocardium. Most knowledge, theories, hypotheses and proofs have come from the CVB3-mouse work, mainly with the strain Nancy. CVB3-mouse studies have been carried out in inbred, semi-inbred, congenic, and isogenic mice.

\section{Susceptibility of mice}

CVB3 infection induces myocardial inflammation and myocyte necrosis in some strains of mice. Genetically well-defined mice strains that differ in MHC H-2 have been used to study myocarditis and autoimmunity triggered by CVB viruses. Woodruff and Kilbourne (1970) developed a myocarditis model using inbred Balb/c mice $\left(\mathrm{H}-2^{\mathrm{d}}\right)$. Gauntt et al.(1984) compared the severity of myocarditis induced by CVB3 variants in different $\mathrm{H}-2$ haplotypes and Lyt phenotypes, and differences linked to mouse gender. The strains of mice examined were CD-1 (semi inbred), SWR/J, 129/J, CBA/T6J, Balb/c, C57BL/6H, C57BL/6J, C57BL/6JLYT1.1, C57BL/6J-LYT2.1, -LYT3.1, C57BL/6J H-2k , C57BL/6J H-2 ${ }^{\mathrm{k}}$ CE-LYT 2.1.DS, C3H CE LYT 1.2., DS LYT, DBA/2J, C58/J, BIO-D2/ ${ }_{\mathrm{NU}}^{\mathrm{NS}}$, and C57BL/6J H-2 . Mice sharing H-2 haplotypes, carrying $\mathrm{b}$ and $\mathrm{k}$ alleles were resistant even to the virulent strains. Lyt genes were an important factor that affected susceptibility. When the strain of CVB3 differed (i.e., the virus strain was myocarditic), the $\mathrm{H}-2$, Lyt $-1,-2$ and -3 loci played an important role. The Balb/c mice with $H-2^{q}$ were more susceptible than SWR inbred mice with $H-2^{q}$ when infected with a virulent virus strain.

Susceptibility of experimental mice to the CVB3 strain Nancy in SWR A.BY/SnJ H-2d, A.SW/SnJ H-2 ${ }^{\text {s }}$ A.CA/SnH $H-2^{f}$, B10.S/SgSf $H-2^{\text {s }}$, B.10.PL/SgSf $H-2^{\text {u }}$ and C3H.NB/SnJ $H-2^{\mathrm{p}}$ was studied by Wolfgram et al. (1985). Zhang et al. (1994) compared susceptibility of genetically defined CVB3 virus and different plaque phenotypes. SWR mice developed severe myocarditis and pancreatitis.

\section{Viral persistence}

CVB infection and persistence of viral RNA leading to direct damage of the cardiomyocytes have been studied by Andreoletti et al. (1997), Kandolf et al. (1993), and Klingel et al. (1993). Mice used in these studies were A/J H-2a, A.CA/J H-2 $2^{\text {f }}$ A.By/J H-2, and SWR/JH-2q . Other mice used for CVB3 and viral persistence studies were SWR/J,129/J, Balb/c, and CBA/T6J. Besides these, A.CA/J, A.BY.J, A.SW/J. SWR.J mice have been reported to show high virus loads in heart muscles in contrast to C57BL/6 or DBA1/J (Klingel, 2003). CVB3 persistence in the inbred mouse strains has been reviewed by Chapman and Kim (2008).

In $\mathrm{AC} 3 \mathrm{H} / \mathrm{HeJ}$ and $\mathrm{A} / \mathrm{J}$ mice, when infected with nine different strains (avirulent, pancreovirulent only, and cardiovirulent), all strains were shown to replicate well and the virus persisted in the pancreas through eight days post-inoculation (Tracy et al., 2000). The cardiovirulent CVB3 strains replicated to a higher titer earlier and persisted longer in sera, pancreatic, and cardiac tissues than the noncardiovirulent strains.

\section{Immunity and mouse strains}

Neu et al. (1987a,b) and Rose et al. (1987) showed that C57BL/10, C57BL/6, and B10.A were resistant to the latephase of disease (myocarditis). The authors showed that the autoimmunity to cardiac myosin and the $\mathrm{H}-2$ haplotype of the mouse were involved. A.SW mice had higher titers than B10.S mice though they shared the $\mathrm{H}-2$ haplotypes, whereas A.By mice showed higher titers than A.CA mice, which differed only in the H-2 locus (Herskowitz et al., 1985; Wolfgram et al., 1985). The A backgrounds of mice such as $\mathrm{A} / \mathrm{J}\left(\mathrm{H}-2^{\mathrm{a}}\right)$ and A.SW $\left(\mathrm{H}-2^{\mathrm{s}}\right)$ differ only in the MHC, but develop moderate to severe inflammation following infection with CVB3 on immunization with cardiac myosin. But B strains of mice with the same $\mathrm{H}-2$ haplotype on a C57BL/10 background B10.A (H-2 $\left.{ }^{\mathrm{a}}\right)$ and B10.S (H-2 $)$ background mice resist the induction of autoimmune type reaction. These studies show that it is important to know the background of the mice. The autoimmune aspects of coxsackievirus infection have been reviewed by Rose (2008).

Other mouse strains that have been used in the CVB3 murine model were Balb/c (Huber and Lodge, 1984); Balb/c and C57BL/6 (Leipner et al., 2004); semi-inbred, e.g., CD-1 (Gauntt et al., 1984); and outbred, e.g., NMRI (Glück., 2001; Merkle et al., 1999; Schmidtke et al., 2007). A difference in the interleukin 6 (IL-6) and tumor necrosis factor-alpha (TNF- $\alpha$ ) production kinetics in response to CVB3 existed between the CD-1 and $\mathrm{C} 3 \mathrm{H}$ mouse strains, and this difference was related to reduced contractile performance (Seko et al., 1998). SWR/Harlan $H-2^{q}$ mice showed viral persistence in the heart of CVB3 infected mice at day 90-post-infection (p.i.) (Reetoo et al., 2000).

The availability of different combinations of transgenic and knockout mice (e.g. SCID) has also helped in understanding the role of immune responses to CVB3 
(Schwimmbeck et al., 2000). Single knockouts such as CD8 or CD4 knockout on A/J background, TCR a/b knockout (Opavsky et al., 1999), $\beta 2$-microglobulin and perforin knockout ( $\beta 2 \mathrm{~m}$-/- and perforin-/-) in C57BL/6 mice (Klingel et al., 2003) have helped to show the importance of a particular gene or immune reaction. Other immune and cytokine responses that have been studied in SCID mice lacking B- and T- cells showed severe myocardial damage leading to death of mice (Chow et al., 1992; Opavsky et al., 1999). IL-6 deficient mice, RAG-2 deficient mice lacking both B cells and T cells, and $\mu \mathrm{MT}$-deficient mice lacking $B$ cells more than 8 generations backcrossed to BALB/C and $\mathrm{IL}^{-6 / /+} \mathrm{Balb} / \mathrm{c}$ have also been used to study the IL-6, $\mathrm{T}$ cells, and the autoimmune myocarditis (Erikson et al., 2003). Balb/c mice were studied for the protective effect of CVB3/IFN- $\gamma$ by application of the recombinant virus by different routes (Henke et al., 2007). Mena et al. (1999) have shown the importance of B cells as targets in early infection and as a means of CVB3-Nancy dissemination to different tissues. For these studies specialized BcKO $\mu \mathrm{Mt} /$ $\mu \mathrm{Mt}(-/-)$ mice which were $H-2^{b}$, B cell-knockout membrane $\mu$ chain deleted and B cell development in homozygous mice arrested at or before pre-B cell stage were used.

The effect of MHC class II IA and IE expression on myocarditis susceptibility in four transgenic C57BL/6 mouse strains differing in MHC class II antigen expression was shown by Huber et al. (1999). In these studies, animals lacking MHC class II IE antigen (C57BL/6 $\left[\mathrm{IA}^{+} \mathrm{IE}^{-}\right]$and $\mathrm{AB}^{\circ}$ $\left[\mathrm{IA}^{-} \mathrm{IE}^{-}\right]$) developed minimal cardiac lesions subsequent to infection in the heart. Whereas mice with IE ( $\mathrm{AB}^{\circ} \mathrm{Ea}\left[\mathrm{IA}^{-}\right.$ $\left.\mathrm{IE}^{+}\right]$and Bl.Tg.E $\alpha\left[\mathrm{IA}^{+} \mathrm{IE}^{+}\right]$) showed cardiac injury. Female and male transgenic mice SOCS-1-Tg, non-Tg NOD mice, SOC-1-Tg, non-Tg NOD.SCID mice interferon (IFN) alpha ( $\alpha$ ), beta ( $\beta$ ), and gamma ( $\gamma$ ) (R.sup.-/-) mice on 129S6/SvEv background and wild-type 129S6/SvEv mice were used to show the protection of islet cells and observe the role of the cytokine production on local cell destruction when infected with CVB3, murine cytomegalovirus (MCMV) and lymphocytic choriomeningitis virus (LCMV) infection (Flodstrom et al., 2003).

C57BL/6 PVR IFNAR+/+ and C57BL/6 PVR IFNAR-/mice were used by Wang and Pfeiffer (2016). They showed phenotypic differences in the coxsackieviruses isolated from the feces and other organs, and also between orally and intraperitoneally infected mice. A large-plaque variant of CVB3 was found in mice infected by the oral route from the feces.

\section{Secondary infections}

Primary infection with CVB2 and a secondary infection after 28 days with a mutant CVB3 in C3H/HeJ mice induced severe myocardial inflammation (Beck et al.,
1990). A higher impact of secondary heterotypic infection was observed when comparing with homotypic infection, using primary CVB2 infection followed by CVB3 and CVB3 primary followed by CVB3 infection at different days postinfection of A/JH-2 ${ }^{\mathrm{a}}$ mice (Yu et al., 1999).

\section{Mouse strains and CVB4}

\section{Diabetes}

CVB4 has been related to human heart diseases, acute and chronic pancreatitis, and type 1 diabetes (T1D). CVB4 infections in mice are related mainly to the pancreas: T1D or pancreatitis. Before initiation of mouse studies, one should understand the passage history of the CVB strain, which is important in the ultimate understanding of the viral pathogenesis or the disease process in the mice.

The most commonly used virus strains related to T1D or experimental models are mainly the CVB4-E2 strain or CVB4-JVB strain. The E2 strain of CVB4 was isolated from the pancreas of a child who died following an aggressive virus infection associated with diabetic ketoacidosis (Yoon et al.,1979). The virus isolated from the pancreas was passed through murine pancreatic cells and identified as CVB4. When injected into mice, it was shown to induce hyperglycemia and a diabetes-like disease. Since then, it has been widely used as a diabetogenic strain of the CVB4.

Passage history and mouse strain were responsible for the induction of diabetes by the CVB4-E2 strain and the encephalomyocarditis virus (EMC) D strain (Notkins et al., 1979). They studied the infection by these two viruses in SJL/J, SWR/J, NIH/Swiss, C57BL/6J, CBA/J, $\mathrm{C} 3 \mathrm{H} / \mathrm{J}, \mathrm{DBA} 1 / \mathrm{J}, \mathrm{DBA} 2 / \mathrm{J}$ mice of both genders, and in only males of AKR, BALB/C strains. The male SJL/J, SWR/J, $\mathrm{NIH} /$ Swiss strains were more diabetic than the females of the same type of strains and the other tested strains. Further Hartig et al. (1983) infected C57B1/6 and SWR mice with the Edwards isolate of CVB4 (CVB4-Edw) and three of its plaque-purified "strains". These were designated Edward's isolate E1, E2, and E3. Isolate (strain) E2 showed the most intense accumulation of antigen in islet cells. From these observations, Hartig et al. (1983) suggested that the Edwards isolate of CVB4, like other human isolates of CVB4, probably exists as a heterogeneous population. They concluded that the pathogenic consequences and expression of any diabetogenic potential is dependent on the virus strain selection. This diversity in the pathogenesis of the virus must be considered when evaluating the pathogenic nature of CVB4 viruses in experimental animals and the possible role of the viruses in diabetes of man (Hartig et al., 1983). Since that time, the E2 strain has been widely used as compared to other CVB4 strains 
as a diabetogenic strains of the CVBs, especially when the complete nucleotide sequence of this strain was compared to the JVB strain (Kang et al., 1994).

Chatterjee et al. (1985) have shown alteration in the protein and insulin synthesis of mouse $\beta$ cells and the blood glucose tests of CD-1 mice infected with the virus CVB4-E2. In these mice hyperglycemia developed following the injection of CVB4-E2 strain by See and Tilles (1995).

\section{Pancreatitis}

CVB4-JVB (CVB4-P) strain was isolated in New York/ US in 1951 by Benschoten (Jenkins et al., 1987). CVB4-P variant induces damage to the exocrine pancreas in humans (Bradley, 1994). A comparison of the sequences of the two CVB4 well known strains, the JVB and E2 strain has shown numerous nucleotide differences (Caggana et al., 1993; Chapman et al., 1997; Ramsingh et al., 1997). The other variant CVB4-V is designated as "virulent" since it induces a disease syndrome characterized by chronic pancreatitis, hypoglycaemia, and myocarditis (Caggana et al., 1993; Ramsingh, 1997; Ramsingh et al., 1999). The non-diabetogenic prototypic strain, which causes a mild, acute pancreatitis without morbidity, or mild pancreatic damage (as determined by histological studies) is minimal and transient; therefore, CVB4-P is designated avirulent in mice (Ramsingh, 1997; Ramsingh et al., 1984; 1997; 1999). The B10.T (6R), B10.S (12R) and Balb/c mice infected with CVB4-V developed a chronic pancreatitis with extensive damage to the exocrine pancreas (Halim and Ramsingh, 2000). Follow-up studies of CVB4-V-infected mice reveal prolonged acinar injury. The importance of different cytokines has been shown by knockout (ko) mice such as IFN $\gamma \mathrm{KO}(\mathrm{GKO}$ ) on Balb/ cByJ background, B10H-2 congenic strains, B10.T(6R), B10.S(12R) on the BALB/cByJ background, CD4 ko, IL-4 ko and gamma interferon ko, the $\mathrm{T}$ cell receptor transgenic D011.10 strain expressed on Balb/c background, BALB/ cByH-Hfh $11^{\text {nu }}$ (nude) BALB/cBySmn-Prkdcscid severe combined immunodeficient (SCID) on BALB/c background (Potvin et al., 2003).

SJL male mice have been used by Palma et al. (2008) to study pancreatitis and metalloproteinase 9 in CVB4-E2 infected mice, and this enzyme was shown to originate from macrophages and neutrophils. Yap et al. (2003) compared infection of SJL/J mice CVB4-E2 strain and CVB4-JVB. Both strains were shown to replicate in the pancreas and induced pancreatitis, however CVB4-JVB showed regeneration of islet cells. The authors have suggested that the beta cell depletion in the E2 strain infected animals is due to lack of the neogenesis process and not to the virus-induced cell death, though the islets maybe infected.

\section{Inbred and knockout mouse strains and CVB}

CVB4-E2 and LCMV infections were compared by Horwitz et al.(1998) in different transgenic NOD/shi mice with MHC allele to understand which cross-reactive epitope is restricted (NOD/scid mice, B10.H2 ${ }^{\mathrm{g} 7}$ mice, non-Tg BDC2.5 mice, and BDC2.5 Tg mice). The authors have suggested that viral induction of diabetes depended on the $\mathrm{T}$ cells and the $\mathrm{T}$ cell receptor. They implied that the molecular mimicry and direct tissue damage were responsible (bystander effect).

Studies of female NOD Mrk/Tac mice did not show T1D on infection with different CVB3 strains or with CVB4-E2 and CVB4-JVB. The different phenotypes studied showed various properties such as myocarditic and pancreovirulent, non myocarditic but pancreovirulent, and totally nonvirulent in either heart or pancreas. Infection with certain strains (among which were the CVB4 strains) showed greater protection against virus infection; this protection was greater in more pathogenic strains than in less virulent or avirulent strains. Virus-induced pancreatitis and induction of an autoimmune pancreatitis were observed. In addition, CVB infection of younger NOD mice was protective, reducing the risk of T1D onset. On the basis of these studies, Tracy et al. (2002) suggested a vaccine-mediated suppression in the future. Drescher et al. (2004), used the same strain of NOD mice, the same CVB3 strains, and a CVB3-IL-4 chimeric strain (where mice were treated first with poly I:C). The authors suggested that complex CVB genetics and the immune reactions induced by each strain mediate a specific and crucial role in the etiology of T1D.

Other NOD mice studies (Serreze et al., 2005) NOD/ Lt, NOD-IL-4-/-, also known as NOD- $I L-4^{\mathrm{tmJ} / \mathrm{Cgn}}$, and NOD IFN- $\gamma-/-$, and NOD-Ifng- $4^{\text {tmJ/Ts }}$, all with NOD background, were infected with CVB4-E2. These studies suggest that the insulitis threshold at which CVB4 infection can accelerate the onset of diabetes in NOD mice is increased by IL-4 and IFN- $\gamma$, but the protective effect against diabetes in NOD mice is induced by CVB4 prior to the development of a critical threshold level of insulitis and does not require IL-4 or IFN- $\gamma$.

Strain-influenced differences related to inflammation, insulin secretion, and pro-insulin synthesis, beta cell dysfunction on infection of CBA/J mice with different strains of CVB such as CVB4-E2 and CVB3-Nancy were observed by Hindersson et al. (2004).

\section{Other viruses and mice}

Al-Hello et al. (2005) have shown that repeated passages of a laboratory strain of coxsackievirus B5 in the mouse pancreas in vivo caused a phenotypic change in 
the virus after 15 passages. Infection of SJL mice with this variant resulted in a diabetes-like syndrome characterized by chronic pancreatic inflammation together with dysregulation in glucose metabolism, loss of pancreatic acinar tissue, and mild insulitis. This was related to eight nucleotides changes resulting in five amino acid substitutions, of which three were located in the capsid proteins in the variant.

Balb/c mice were used by Harvala et al.(2003) to analyze the role of arginine glycine aspartic acid (RGD) motif of CVA9 (substitution, deletion and insertion mutants) on tissue tropism and pathogenicity. The mice were infected with parental (CVA9) and different mutants of RGD motif to show its significance in the pathogenesis of CAV9.

Feuer et al. (2003) infected Balb/c neonates intracranially to investigate the tropism and pathology of CVB3 using the recombinant virus expressing the enhanced fluorescent protein (eGFP-CVB3) where the neonatal stem cells were thought to carry the CVB to the parenchyma of the developing neurons.

Literature survey shows very few research studies on the experimental oral CV infection to which less attention has been paid due to mostly technical problems such as accuracy of the dose received by the mouse and mild pathology after the infection. The early studies conducted by Loria et al. (1974a,b, 1977) or Kaplan and Melnick (1951) in newborn CD-1 mice showed a lower rate of paralysis and death in mice inoculated by the oral route when infected with a CVB5 isolate. A replicating virus was observed in all organs showing presence of systemic infection. Loria et al. (1974a) also showed susceptibility of CD-1 adult mice to oral infection in the absence of visible clinical manifestations by using the CVB5 clinical isolate from an aseptic meningitis case. In our laboratory Swiss albino outbred mice were used for studying the oral infection with CVB1 (Petrovicova 1983; unpublished results) and CVB3 virus (Bopegamage et al., 2003, 2005). Results of these studies will be discussed further in the next section.

Oral infection of CVB1 and CVB3-Nancy in pregnant CD-1 mice in the gestation period produced maternal viremia and transplacental transmission of the virus (Modlin and Crumpacker, 1982; Modlin and Bowman, 1987). Oral infection of neonatal mice with different clinical isolates of EV-71 passaged in intestinal organ cultures or in cell lines such as CaCO-2, neuroblastoma (SK-N-SH) or common kidney epithelial cells, has been reported by Chen et al. (2004).

Major variables in CVB3 induction of inflammatory heart disease and outcomes of the infection in murine models have been identified as viral genotype, sex, age, and genetic background, immunological and nutritional status of the host, and the innate and immunologic system responses to the CVB infection (Gauntt et al., 1993; Gauntt et al., 1995; Gauntt, 2003). These variables should apply to the diseases caused by these viruses in mice and in humans, though many questions yet remain to be answered.

On one hand, among the murine models considering the 3Rs, mice are the best models for studying the coxsackieviruses. There always have been and always will be debates over the pros and cons of using animal models in general, as well as over particular models such as diabetes and NOD mice (Leiter and von Herrath, 2004; Roep and Atkinson, 2004; Roep et al., 2004). Scientific history shows us, however, that we cannot study a disease completely without using animal models.

\section{Our work}

In $1992,23 \%$ of the viral isolates from stool samples of the juvenile diabetic patients were identified as CVA7 or CVA9. Two of the isolates were selected (CVA7 and CVA9). The patients also showed the presence of IgM antibodies to CVA7 and CVA9 respectively. The chosen isolates and a prototype laboratory CVB4-JVB strain were shown to be capable of infecting islet cells of Swiss albino mice in vitro (Bopegamage and Petrovicova, 1994). The CVA9 isolate was later shown to be phylogenetically related to a genetic subcluster of echovirus 11 (Al-Hello et al., 2008). The CVA7 isolate, the prototype strains CVA7-Parker and CVB4-JVB were shown to induce serum TNF- $\alpha$ in Swiss albino mice (Bopegamage and Petrovicova, 1998).

Loria et al. (1974 a,b) showed that adult mice similar to the suckling mice are susceptible to infection with CVB viruses by both oral and intraperitoneal routes. In the older host, the intestinal tract provided considerable protection against peroral infection. The protection, according to these authors, consisted of at least two separate components: 1) a barrier effect that prevented passage of the virus from the intestinal lumen through the gut mucosa and into the circulatory system and 2) a clearance mechanism that eliminated the virus from the enteric tract after infection had occurred. As the natural portal of entry of these viruses is the oral route and considering the previous experiences in our laboratory and also the published literature, especially the studies by Loria et al. (1974 a, b), we have carried out several studies using the oral route of infection in the murine model and following up the pathology.

Our studies in the murine model using the oral infection

In our first studies we infected three- to four-weekold Swiss albino mice with CVB3-Nancy and CVB4-JVB (Bopegamage et al., 2003). Replicating virus was present 


\begin{tabular}{|c|}
\hline CVB3-Nancy \\
CVB4-JVB \\
CVB5-Fl \\
CVB2-O \\
CVB5 - isolates clinical \& \\
\hline
\end{tabular}

CVB2-Ohio

\section{Swiss albino, CD1}

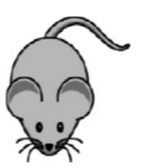


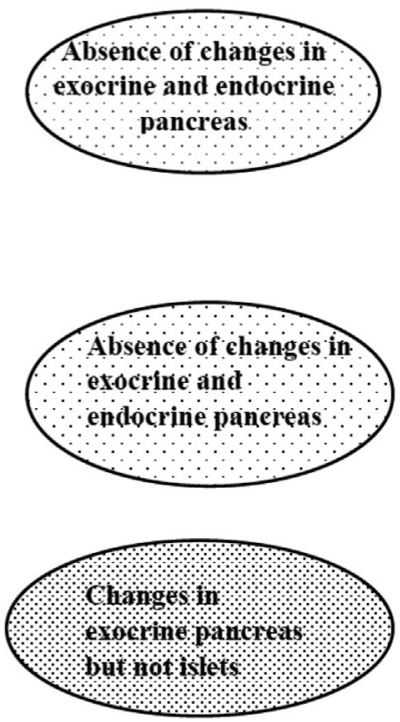

\section{CD1 dams and challenged offspring}

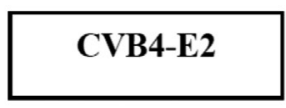

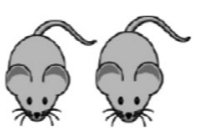

Fig. 1

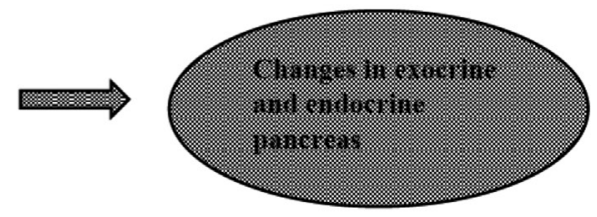

Oral infection of different mice strains with various coxsackieviruses

Illustration of factors influencing the pathophysiology of coxsackievirus infection by the oral route in experimental mouse models used in our work.

in the heart, thymus, spleen, pancreas, and the large and small intestines. At a late phase of infection, the CVB4-JVB infected mice showed infiltration of necrotic myocardial cells, with mononuclear cells and fat cells in the heart on day 56 p.i. and 71 p.i., without histopathological changes in the pancreas (Bopegamage et al., 2003). For location of the viral antigen, we used the VP1 antibody and immunohistological (IHC) analysis. This method was modified and applied by us later on (Drescher et al., 2004). Initially we pooled samples from 3 or 5 mice per observation, making it impossible to analyse inter-individual variations.
Therefore, a systematic study was carried out (Bopegamage et al., 2005) where we infected Swiss albino mice with CVB3-Nancy at different doses, via the intraperitoneal route and parallelly by the oral route, each organ sample from each mouse was collected separately. We were not able to find a definite "threshold-of-infection dose", but $1 \times 10^{8} \mathrm{TCID}_{50} / \mathrm{ml}$ was found to be the optimum. The pancreas of the orally infected mice did not show histopathological changes, yet we localized the viral VP1 antigen in the exocrine and endocrine pancreas, independent of route and dose of infection. VP1-staining is 
not correlated with inflammation and necrosis, which indicated some state of innate protection. We also studied IFN- $\alpha$ involvement in the protection. Virus and IFN- $\alpha$ were located in the endocrine and exocrine pancreas, independent of the route and dose of infection. IFN- $\alpha$ and virus VP1 were still present long after infection in some (not all) mice.

Later on, we studied (Precechtelova et al., 2015) oral infection of different mouse strains with different genetic backgrounds with CVB4-E2. We used 1) outbred (Swiss albino and CD1), 2) inbred (SJL, non-obese diabetic [NOD]), and 3) transgenic (NOD.SCID) mice. This study showed that the host genetics did not influence the histopathology or the function of the infected pancreatic islets. The inflammation of the exocrine pancreas depends not only on the route of infection but also on the CVB strain, mouse genetics and immune system. The endocrine pancreas was not affected in any of the infected mice. We observed that CVB4-E2 strain induced peripancreatic fat infiltration whereas, pancreatitis was observed only in the NOD.SCID mice. In addition, we observed mortality in the NOD and NOD.SCID mice which was related to heart pathology and immense inflammation of the heart.

Furthermore, CVB5 isolates from the cerebrospinal fluid and stool of an aseptic meningitis patient, when given orally to mice did not cause any histopathological changes in the pancreas but showed mild inflammation in the heart (unpublished data). Also, our unpublished data show that the wild type strain of CVB2-Ohio does not induce any changes in the endocrine and exocrine pancreas but mild inflammation in the heart.

Our studies (Bopegamage et al., 2012; Sarmirova et al., 2019) on the effect of gestational infection by CVB4-E2 on the pancreas of both dams and their challenged pups showed that the replicating virus was present in the pancreas of infected dams and their challenged pups. We also observed presence of inflammation leading to chronic necrotizing pancreatitis and atrophy of the acinar tissue of the dams and their offspring. The IHC analysis showed difference in the type of infiltrating cells between the pups and the dams. Time of infection during gravidity and time of collection of samples after infection influenced the pancreatic pathophysiology in both groups.

In conclusion as seen in figure 1, we may say that the oral infection of mice with coxsackieviruses often induces mild to severe inflammation in the heart. The exocrine and endocrine pancreas are not affected when outbred strains were infected. In specific strains of mice CVBs may induce pancreatitis, but the islets are not affected. Whereas, when pregnant mice were infected not only the dams but also the pups showed severe pancreatitis and infiltration in the islets. This gives rise to a number of questions such as: What exactly is the role of infection by the CVBs during gravidity? We suggest that more studies are required additional attention should be focussed on enteroviral infections during pregnancy which may affect the health of the offspring even in humans.

Acknowledgments. We thank the project of the Ministry of Health MZSR 2016/3-RUVZBB-3, Norwegian financial support mechanism, Mechanism EEA and Slovak Government - Project SK0082 received by S.B. Centre of excellence of environmental health, ITMS No. 26240120033, operational Research and development program financed from the European Regional Development Fund. We also thank the National Reference Centre for Identification of Enteral Viruses, Ministry of Health of the Slovak Republic.

\section{References}

Al-Hello H, Davydova B, Smura T, Kaialainen S, Yliaasto P, Saario E, Hovi T, Rieder E, Roivainen M., J. Med. Virol. 75, 566-574, 2005. https://doi.org/10.1002/jmv.20303

Al-Hello H, Paananen A, Eskelinen M, Ylipaasto P, Hovi T, Salmella K, Lukashev AN, Bopegamage S, Roivainen M., J. Gen.Virol. 89,1949-1959,2008. https://doi.org/10.1099/ vir. 0.83474-0

Andreoletti L, Hober D, Becquart P, Belaich S, Copin MC, Lambert V, Wattre P., J. Med. Virol. 52, 206-214, 1997. https://doi. org/10.1002/(SICI)1096-9071(199706)52:2<206::AIDJMV15>3.0.CO;2-I

Beck MA, Chapman NM, McManus BM, Mullican JC, Tracy T., Am. J. Pathol. 136, 669-681, 1990.

Bergelson JM, Cunningham JA, Droguett G, Kurt-Jones EA, Krithivas A, Hong JS, Horwitz MS, Crowell RL, Finberg RW., Science 275, 1320-1323, 1997.

Bergelson JM, Krithivas A, Celi L, Droguett G, Horwitz MS, Wickham T, Crowell RL, Finberg RW., J. Virol. 72, 415-419, 1998. https://doi.org/10.1128/JVI.72.1.415-419.1998

Bopegamage S., Virulence 3, 495-497, 2016. https://doi.org/10.1 080/21505594.2016.1175701

Bopegamage S, Borsanyiova M, Vargova A, Petrovicova A, Benkovicova M, Gomolcak P., Acta Virol. 47, 245-251, 2003.

Bopegamage S, Kovacova J, Vargova A, Motusova J, Petrovicova A, Benkovicova M, Gomolcak P, Bakkers J, van Kuppeveld F, Melchers WJG, Galama JM., J. Gen. Virol. 86, 3271-3280, 2005. https://doi.org/10.1099/vir.0.81249-0

Bopegamage SA, Petrovicova A., Acta Virol. 38, 251-255, 1994.

Bopegamage SA, Petrovicova A., Acta Virol. 42, 409-412, 1998.

Bopegamage S, Precechtelova J, Marosova L, Stipalova D, Sojka M, Borsanyiova M, Gomolcak P, Berakova K, Galama J., FEMS Immunol. Med. Microbiol. 64, 184-190, 2012. https://doi.org/10.1111/i.1574-695X.2011.00886.X

Bradley EL., Raven Press: New York, 94-100, 1994.

Caggana M, Chan P, Ramsingh A., J. Virol. 67, 4797-4803, 1993. https://doi.org/10.1128/JVI.67.8.4797-4803.1993

Chapman NM, Kim KS., Curr. Top. Microbiol. Immunol.275-292, 2008. 
Chapman NM, Ramsingh AI, Tracy S., Curr. Top. Microbiol. Immunol. 223, 227-258, 1997. https://doi.org/10.1007/9783-642-60687-8_11

Chatterjee N, Haley TM, Nejman C., J. Biol. Chem. 260, 1278612791,1985

Chen Y, Yu C, Wang Y, Liu C, Su I, Lei H., J. Gen. Virol. 85, 69-77, 2004. https://doi.org/10.1099/vir.0.19423-0

Chow LH, Beisel KW, McManus BM., Lab. Inves. 66, 24-31, 1992.

Dalldorf G, Melnick JL., In Viral and Rickettsial infections of man. 472-512, 1965.

Dalldorf G, Sickle GM, Science 108, 61-62, 1948. https://doi. org/10.1126/science.108.2794.61

de Verdugo UR, Selinka HC, Huber S, Kramer B, Kellermann J, Hofschneider PH, Kandolf R., J. Virol. 69, 6751-6757, 1995. https://doi.org/10.1128/JVI.69.11.6751-6757.1995

Drescher K, Kono K, Bopegamage S, Carson SD, Tracy S., Virology 329, 381-394, 2004. https://doi.org/10.1016/j. virol.2004.06.049

Erikson U, Kurrer MO, Schmitz N, Marsch SC, Fontana A, Eugster H, Kopf M., Circulation 107, 320-325, 2003. https://doi. org/10.1161/01.CIR.0000043802.38699.66

Feuer R, Mena I, Pagarigan R, Harkins S, Hassett DE, Whitton JL., Am. J. Pathol. 163, 1379-1385, 2003. https://doi. org/10.1016/S0002-9440(10)63496-7

Flodstrom M, Tsai D, Fine C, Maday A, Sarvetnick N., Diabetes 52, 2025-2034, 2003. https://doi.org/10.2337/diabetes.52.8.2025

Frisk G, Diderholm H., J. Infect. 34, 205-210, 1997. https://doi. org/10.1016/S0163-4453(97)94143-8

Gauntt CJ, Arizpe HM, Higdon AL, Wood DF, Bowers DF, Rozek MM, Crawley R., J. Immunol. 154, 2983-2995, 1995.

Gauntt CJ, Gomez PT, Duffey PS, Grant JA, Trent DW, Witherspoon SM, Paque RE., J. Virol.52, 598-605, 1984. https:// doi.org/10.1128/JVI.52.2.598-605.1984

Gauntt CJ, Higdon A, Bowers D, Maull E, Wood J, Crawley R., Scand. J. Infect. Dis. Suppl. 88, 49-65, 1993.

Gauntt CJ, Huber S., Frontiers of Biosciences 8, 23-35, 2003. https://doi.org/10.2741/928

Gifford R, Dalldorf G., Am. J. Pathol. 27, 1047-1064, 1951.

Glück B, Schmidtke M, Merkle I, Stelzner A, Gemsa D., J. Mol. Cell. Cardiol. 33, 1615-1626, 2001. https://doi.org/10.1006/ imcc.2001.1416

Halim S, Ramsingh A., Virology 269, 86-94, 2000. https://doi. org/10.1006/viro.2000.0188

Hartig PC, Madge GE, Webb SR., J. Med. Virol. 11, 23-30, 1983. https://doi.org/10.1002/imv.1890110104

Harvala H, Kalimo H, Dahllund L, Santti J, Hughes P, Hyypia T, Stanway H., J. Gen. Virol. 83, 1697-1706, 2002. https:// doi.org/10.1099/0022-1317-83-7-1697

Henke A, Jarasch N, Martin U, Zell R, Wutzler P., Vir. Immunol. 21,38-48, 2007. https://doi.org/10.1089/vim.2007.0077

Herskowitz A, Beisel KW, Wolfgram LJ, Rose NR., H. Pathol. 16, 671-673, 1985. https://doi.org/10.1016/S0046$\underline{8177(85) 80149-0}$

Hindersson M, Orn A, Harris RA, Frisk G., Arch. Virol. 149, 1985-2000, 2004.

Horwitz MS, Bradley LM, Harbertson J, Krahl T, Lee J, Sarvennick N., Nat. Med. 4, 781-785, 1998. https://doi. org/10.1038/nm0798-781
Huber SA, Lodge PA., Am. J. Pathol. 116, 21-29, 1984.

Huber S, Kupperman J, Newell M., J Virol. 73, 4689-4695, 1999. https://doi.org/10.1128/JVI.73.6.4689-4695.1999

Hyoty H, Hiltunen M, Lonnrot M., Clin. Diag. Virol. 9, 77-84, 1998. https://doi.org/10.1016/S0928-0197(98)00007-5

Hyoty H, Taylor KW., Diabetologia 45, 1353-1361, 2002. https:// doi.org/10.1007/s00125-002-0852-3

Ito M, Kodama M, Masuko M, Yamaura M, Fuse K, Uesugi Y, Hirono S, Okura Y, Kato K, Hotta Y, Takao H, Kuwano R, Aizawa A., Circ. Res. 86, 275-280, 2000. https://doi. org/10.1161/01.RES.86.3.275

Jenkins O, Booth J, Minor P, Almond J., J. Gen. Virol. 68, 18351848,1987. https://doi.org/10.1099/0022-1317-68-7-1835

Jun HS, Yoon JW., Diabetologia 44, 271-285, 2001. https://doi. org/10.1007/s001250051614

Kandolf R, Klingel K, Zell R, Selinka HC, Raab U, SchneiderBrachert W, Bultmann B., Intervirol. 35, 140-151, 1993. https://doi.org/10.1159/000150305

Kang Y, Chatterjee NY, Nodwell MJ, Yoon JW., J. Med. Virol. 44, 353-361,1994. https://doi.org/10.1002/imv.1890440408

Kaplan AS, Melnick JL., Proc. Soc. Exp. Biol. Med.76,312-315, 1951. https://doi.org/10.3181/00379727-76-18475

Kim KS, Hufnagel G, Chapman N, Tracy S., Rev. Med. Virol. 11, 355-368, 2001. https://doi.org/10.1002/rmv.326

Klingel K., In: Myocarditis from bench and bedside. 295-324, 2003.

Klingel K, Hohenadi C, Canu A, Albrecht M, Seemann M, Mall G, Kandolf R., Proc. Natl. Acad. Sci. USA 89, 314-318, 1992. https://doi.org/10.1073/pnas.89.1.314

Leipner C, Grün K, Schneider I, Gluck B, Sigusch HH, Stelzner A., Med. Microbiol. Immunol.193,141-147,2004.https:// doi.org/10.1007/s00430-003-0199-5

Leiter EH, von Herrath M., Diabetol.47,1657-1660, 2004. https:// doi.org/10.1007/s00125-004-1518-0

Loria RM, Kibrick S Broitman SA., J. Inf. Dis. 130, 225-230, 1974 a. https://doi.org/10.1093/infdis/130.3.225

Loria RM, Kibrick S, Broitman SA., J. Inf. Dis. 130, 539-543, 1974b. https://doi.org/10.1093/infdis/130.5.539

Loria RM, Kibrick S, Broitman SA., Am. J. Clin. Nutr. 30, 18761879, 1977. https://doi.org/10.1093/ajcn/30.11.1876

Melnick LM., Fields Virology, 3rd edn. 655-712, 1996.

Mena I, Perry CM, Harkins S, Rodriguez F, Gebhard JR, Whitton JL., Am. J. Pathol. 155, 1205-1215, 1999. https://doi. org/10.1016/S0002-9440(10)65223-6

Merkle I, Tonew M, Glück B, Schmidtke M, Egerer R, Stelzner A., J. Hum. Virol. 2, 369-379, 1999.

Minnich LL, Ray GC., J. Clin. Microbiol. 11, 73-75, 1980. https:// doi.org/10.1128/JCM.11.1.73-75.1980

Modlin JF, Bowman M., J. Inf. Dis. 156, 21-25, 1987. https://doi. org/10.1093/infdis/156.1.21

Modlin JF, Crumpacker CS., Inf. Immun. 37, 222-226, 1982. https://doi.org/10.1128/IAI.37.1.222-226.1982

Muehlenbachs A, Bhatnagar J, Zaki SR., J. Pathol. 235, 217-28, 2015. https://doi.org/10.1002/path.4438

Muir P, Nicholson F, Tilzey AJ, Signy M, English TAH, Banatvala JE., Lancet 1, 804-809, 1989. https://doi.org/10.1016/ S0140-6736(89)92270-8 
Neu N, Beisel KW, Traystman MD, Rose NW, Craig SW., J. Immunol. 138, 2488-2492, 1987a.

Neu N, Rose NR, Beisel KW, Herskowitz A, Craig SW., J. Immunol. 139, 3630-3636, 1987b. https://doi.org/10.1007/978-3642-73610-0_13

Notkins AL, Yoon J, Onodera T, Jenson AB., Adv. Exp. Med. Biol. 119, 137-146, 1979. https://doi.org/10.1007/978-1-46159110-8 21

Noutsias M, Fechner H, de Jonge H, Wang X, Dekkers D, Houtsmuller AB, Pauschinger M, Bergelson J, Warraich R, Yacoub M, Hetzer R, Lamers JMJ, Schuttheiss HP, Poller WC., Circulation 104, 275-280, 2001. https://doi. org/10.1161/01.CIR.104.3.275

Opavsky MA, Penninger J, Aitken K, Wen W, Dawood F, Mak T, Liu P., Circ. Res. 85, 551-558, 1999. https://doi. org/10.1161/01.RES.85.6.551

Pallansch MA, Roos RP., Fields Virology, 839-893, 2007.

Palma AM, Verbeken E, Aelst VI, van den Steen P, Opdenakker G, Neyts J., Virology 382, 20-27, 2008. https://doi. org/10.1016/i.virol.2008.08.046

Potvin DM, Metzer DW, Lee WT, Collins DN, Ramsingh AI., J. Virol. 77, 8272-8279, 2003. https://doi.org/10.1128/ JVI.77.15.8272-8279.2003

Precechtelova J, Borsanyiova M, Sarmirova S, Bopegamage S., J. Pathog.1-20,2014.https://doi.org/10.1155/2014/738512

Precechtelova J, Borsanyiova M, Stipalova D, Sarmirova S, Gomolcak P, Berakova K, Bopegamage S., Arch. Virol.160, 103-115,2015. https://doi.org/10.1007/s00705-014-2236-7

Ramsingh AI., Front. Biosci. 2, 53-62, 1997. https://doi. org/10.2741/A227

Ramsingh AI, Chapman N, Tracy S., Bioessays 19, 793-800, 1997. https://doi.org/10.1002/bies.950190909

Ramsingh AI, Lee WT, Collins DN, Armstrong LE., J. Virol. 73, 3080-3086, 1999. https://doi.org/10.1128/JVI.73.4.3080$\underline{3086.1999}$

Ramsingh AI, Slack J, Silkworth J, Hixson A., Virus Res. 14, 347358,1984.https://doi.org/10.1016/0168-1702(89)90027-0

Reetoo NK, Osman S, Illavia S, Cameron-Wilson C, Banatvala J, Muir P., J. Gen. Virol. 81, 2755-2762, 2000. https://doi. org/10.1099/0022-1317-81-11-2755

Roep BO, Atkinson M., Diabetol.47,1650-1656, 2004. https://doi. org/10.1007/s00125-004-1517-1

Roep BO, Atkinson M, von Harrath M., Nat. Rev. Immunol. 4, 989-991, 2004. https://doi.org/10.1038/nri1502

Roivainen M, Leinikki P, Hovi T, Akerblom HK., Diabetes 44, 652-657, 1995. https://doi.org/10.2337/diab.44.6.652

Rose NR, Beisel KW, Herskowitz A, Neu N, Wolfgram LJ, Alvarez FL, Traystman MD, Craig SW., In: Autoimmunity and autoimmune disease 129, 3-24, 1987.

Rose NR., Curr. Top. Microbiol. Immunol. 323, 294-314, 2008.

Sarmirova S, Borsanyiova M, Benkoova B, Pospisilova M, Arumugam R, Berakova K, Gomolcak P, Reddy J, Bopegamage S., Virulence, 10, 207-221, 2019. https://doi.org/1 $0.1080 / 21505594.2019 .1589364$

Schmidtke M, Merkle I, Klingel K, Hammerschmidt E, Zautner AE, Wutzler P., J. Med. Virol.79, 1334-1342,2007. https:// doi.org/10.1002/jmv.20933
See DM, Tilles JG., J. Inf. Dis. 171, 1131-1138, 1995. https://doi. org/10.1093/infdis/171.5.1131

Seko Y, Takahashi N, Azuma M, Yagita H, Okumura K, Yazaki Y., Circ. Res. 83, 463-469, 1998. https://doi.org/10.1161/01. RES.83.4.463

Selinka HC, Wolde A, Pasch A, Klingel K, Schnorr JJ, Kupper JH, Lindberg AM, Kandolf R., Med. Microbiol. Immunol. 193, 127-131, 2004.

Serreze DV, Wasserfall C, Ottendorfer EW, Stalvery M, Pierce MA, Gauntt C, O'Donnell B, Flanagan JB, Campbell-Thompson M, Ellis TM, Atkinson MA., J. Virol. 79, 1045-1052, 2005. https://doi.org/10.1128/JVI.79.2.1045-1052.2005

Shafren DR., J.Virol.72, 9407-9412,1998. https://doi.org/10.1128/ JVI.72.11.9407-9412.1998

Swanink CM, Melchers WJ, van der Meer JW, Vercoulen JH, Bleijenberg G, Fennis JF, Galama JM., Clin. Infect. Dis. 19, 860-864,1994. https://doi.org/10.1093/clinids/19.5.860

Schwimmbeck PL, Rohn G, Wrusch A, Schulze K, Doerner A, Kuehl U, Tschoepe C, Pauschinger M, Schultheiss HP., Herz 25, 240-244, 2000. https://doi.org/10.1007/ $\underline{\mathrm{s} 000590050013}$

Tracy S, Drescher KM, Chapman N, Kim KS, Carson SD, Pirruccello S, Lane PH, Romero JR, Leser JS., J. Virol. 76, 12097-12111, 2002. https://doi.org/10.1128/ JVI.76.23.12097-12111.2002

Tracy S, Hofling K, Pirruccello S, Lane PH, Reyna SM, Gauntt CJ., J. Med. Virol. 62, 70-81, 2000. https:// doi.org/10.1002/1096-9071(200009)62:1<70::AIDJMV11>3.0.CO;2-R

Vreugdenhil GR, Geluk A, Ottenhoff TH, Melchers WJ, Roep BO, Galama JM., Diabetologia 41, 40-46, 1998. Wang Y, Pfeiffer JK. M. Bio. 29, e00119, 2016. https://doi. org/10.1007/s001250050864

Wolfgram LJ, Beisel KW, Rose NR., J. Exp. Med. 161, 1112-1121, 1985. https://doi.org/10.1084/jem.161.5.1112

Woodruff JF, Kilbourne ED., J. Infect. Dis. 121, 137-163, 1970. https://doi.org/10.1093/infdis/121.2.137

Yap IS, Giddings G, Pocock E, Chantler JK., J. Gen. Virol. 84, 3051-3068, 2003. https://doi.org/10.1099/vir.0.19150-0

Yamayoshi S, Lizuka S, Yamashita T, Minagawa H, Mizuta K, Okamoto M, Nishimura H, Sanjoh K, Katsushima N, Itagaki T, Nagai Y, Fuji K, Koike S., J. Virol. 86, 5686-5696, 2012. https://doi.org/10.1128/JVI.00020-12

Yoon JW, Austin M, Onodera T, Notkins AL., N. Engl. J. Med. 300, 1173-1179, 1979. https://doi.org/10.1056/ NEJM197905243002102

Yu JZ, Wilson JE, Wood SM, Kandolf R, Klingel K, Yang D, McManus MD., Cardiovasc. Pathol. 8, 93-102,1999. https:// doi.org/10.1016/S1054-8807(98)00025-8

Zautner AE, Korner U, Henke A, Badroff C, Schmidtke M., J. Virol. 77, 10071-10077, 2003. https://doi.org/10.1128/ JVI.77.18.10071-10077.2003

Zhang H, Yousef G, Ouyang X, Archard L., Int. J. Exp. Pathol. 75, 99-110, 1994.

www.picornaviridae.com

https://talk.ictvonline.org/taxonomy/;http://www.picornaviridae.com/enterovirus/enterovirus.htm 